\title{
Adenylate Cyclase in Thymus-Derived and Bone Marrow-Derived Lymphocytes from Normal Donors and Patients with Chronic Lymphocytic Leukemia
}

\author{
John Mendelsohn and Judith NoRDBerg, Department of Medicine, University of \\ California, San Diego, La Jolla, California 92093
}

A B S T RACT Lymphocytes were purified from peripheral blood of normal donors and patients with chronic lymphocytic leukemia (CLL) by Ficoll-Hypaque centrifugation. Adenylate cyclase activity, expressed as picomoles [ $\left.{ }^{32} \mathrm{P}\right]$ cyclic AMP generated per milligram protein per minute, was $57 \pm 4$ in normals and $26 \pm 4$ in CLL patients. Enzyme activity, expressed as picomoles [32 P]cyclic AMP generated per $10^{6}$ lymphocytes per minute, was $2.09 \pm 0.19$ for normal lymphocytes and $1.10 \pm 0.16$ for CLL lymphocytes. The differences between normal and CLL peripheral lymphocytes are highly significant $(P<0.001)$ with either method of calculating activity.

Cyclic AMP levels (picomoles per $10^{6}$ lymphocytes) also differed significantly: $1.38 \pm 0.29$ for normals and $0.45 \pm 0.08$ for CLL lymphocytes.

Adenylate cyclase was assayed in lymphocytes enriched for bone marrow-derived (B) cells by removing E-rosetted thymus-derived (T) cells, and enriched for $\mathrm{T}$ cells by harvesting E-rosetted lymphocytes or by removing B cells with nylon wool absorption. Solutions to simultaneous equations gave the following calculated enzyme activities for pure B-and T-cell subpopulations (in picomoles $\left.{ }^{32} \mathrm{P}\right]$ cyclic AMP generated per milligram mg protein per minute): normal $\mathrm{B}, 196 \pm 22$; normal $\mathrm{T}$, $30 \pm 10$; CLL B, $34 \pm 6$; CLL T, $19 \pm 4$. Thus, normal B-lymphocyte adenylate cyclase exceeds normal T-lymphocyte activity by more than sixfold, whereas in the case of CLL the enzyme activity in B lymphocytes is markedly reduced to levels comparable to $\mathrm{T}$ lymphocytes.

Preliminary data from this study was presented at The XII International Leukocyte Culture Conference, Beersheba, Israel, June 1978, and are published in abstract form: 1978. Clin. Res. 26: 536.

Dr. Mendelsohn is the recipient of National Institutes of Health Research Career Development Award CA70891.

Received for publication 19 June 1978 and in revised form 29 January 1979.
The responses of lymphocytes to stimulation with the hormones prostaglandin $\mathrm{E}_{1}$ and isoproterenol, and with $\mathrm{NaF}$, were assessed. Compared with normal lymphocytes, enzyme activities were reduced in CLL lymphocytes incubated with these agents, but to a degree paralleling the reduced basal activities. Thus, the ratios between stimulated and basal adenylate cyclase levels in Ficoll-Hypaque-purified, normal lymphocytes were $2.3 \pm 0.1$ after incubation with $10 \mu \mathrm{M}$ prostaglandin $\mathrm{E}_{1}, 1.8 \pm 0.1$ with $10 \mu \mathrm{M}$ isoproterenol, and $3.9 \pm 0.2$ with $10 \mathrm{mM} \mathrm{NaF}$, values which did not differ significantly from those obtained with CLL lymphocytes. When the enzyme activities calculated for purified T- and B-lymphocyte subpopulations were used to derive the stimulation ratios, the responses of normal and CLL T and B cells to these agents were also indistinguishable. The simplest explanation for these findings is a reduced number of normally responsive enzyme sites on the surface membranes of CLL lymphocytes, although alternative explanations are possible.

\section{INTRODUCTION}

The alterations in cyclic AMP metabolism that accompany human lymphocyte activation have been well characterized $(1,2)$, although the role of these changes remains to be clarified. Abnormalities in cyclic AMP metabolism have been found in lymphocytes from patients with chronic lymphocytic leukemia (CLL) ${ }^{1}$ (3-7). We report here detailed characterizations of adenylate cyclase activity in human thymus-derived (T) and bone marrow-derived (B) lymphocyte subpopulations. These data permit more appropriate

\footnotetext{
${ }^{1}$ Abbreviations used in this paper: BSA, bovine serum albumin; CLL, chronic lymphocytic leukemia; EAC, erythrocyte antibody complement; $\mathrm{Gpp}(\mathrm{NH}) \mathrm{p}, 5^{\prime}$-guanylyl imidodiphosphate; ISO, isoproterenol; $\mathrm{PGE}_{1}$, prostaglandin $\mathrm{E}_{1}$; smIg, surface membrane immunoglobulin; SRBC, sheep erythrocytes.
} 
comparisons to be made between adenylate cyclase activities in malignant and normal human lymphocytes.

\section{METHODS}

Sources of lymphocytes. 21 healthy donors of normal lymphocytes varied in age from 16 to $82 \mathrm{yr}$ old and included 8 females and 13 males. 19 patients with CLL were studied, 14 males and 5 females. The age range was 45-83 yr, with a median of $68 \mathrm{yr}$. The duration of disease was 1-10 yr, with a median of $3 \mathrm{yr}$. Peripheral leukocyte counts varied from 10,000 to $164,000 / \mathrm{mm}^{3}$. Eight patients were untreated, four with counts greater than $30,000 / \mathrm{mm}^{3}$ and four with counts below this level. Seven patients had been treated previously with chlorambucil and(or) prednisone (Lederle Laboratories, Div. of American Cyanamid Co., Pearl River, N. Y.), and two of these had received localized radiotherapy to bulky nodal areas. Four patients were currently under treatment with prednisone or chlorambucil.

Purification of lymphocytes. Lymphocytes were purified from freshly drawn defibrinated blood with previously reported procedures (8). Briefly, the preparative steps involved sedimentation in $1 \%$ dextran (Pharmacia Fine Chemicals Inc., Piscataway, N. J.) to remove the bulk of erythrocytes, followed by centrifugational banding upon an aqueous solution of Ficoll (Pharmacia Fine Chemicals Inc.) and Hypaque (Winthrop Laboratories, New York) at $22^{\circ} \mathrm{C}$. In some cases, noted specifically in the text, additional purification steps were performed. A fraction enriched for B cells was obtained by collecting cells at the interface, after formation of $E$ rosettes with sheep erythrocytes and recentrifugation at $4^{\circ} \mathrm{C}$ on Ficoll-Hypaque $(9,10)$. Purification of a T-cell enriched population was accomplished by incubating FicollHypaque leukocytes on a nylon wool column at $37^{\circ} \mathrm{C}$ for 45 min, followed by gentle elution with medium prewarmed to $37^{\circ} \mathrm{C}(11)$, or by collecting the pelleted E-rosetted lymphocytes and removing erythrocytes. Lymphocytes purified by these various procedures were suspended in Eagle's minimal essential medium (Flow Laboratories, Inc., Rockville, Md.) containing $10 \%$ autologous serum, $2 \mathrm{mM}$ glutamine, $100 \mathrm{U} / \mathrm{ml}$ penicillin, and $100 \mu \mathrm{g} / \mathrm{ml}$ streptomycin. After $60 \mathrm{~min}$ incubation at $37^{\circ} \mathrm{C}$ in $95 \%$ air per $5 \% \mathrm{CO}_{2}$, adenylate cyclase activities and cyclic AMP levels were assayed.

Identification of lymphocyte subpopulations. T lymphocytes were identified by the E-rosette technique. Sheep erythrocytes (SRBC, Colorado Serum Co., Denver, Colo.), 2-wk old and stored in modified Alsever's solution were washed three times in veronal buffer containing $0.1 \%$ pork skin gelatin. A modification of the method of Hepburn and Ritts (12) was used: $1.25 \times 10^{6}$ washed, human lymphocytes in glass round-bottom tubes were suspended in $10 \mu \mathrm{l}$ of a 1:20 dilution of washed SRBC in fetal calf serum (Flow Laboratories, Inc.). An additional drop of serum was then added and mixed by agitation, and the cells were incubated at $37^{\circ} \mathrm{C}$ in a water bath for $15 \mathrm{~min}$, resuspended by twirling, centrifuged at $400 \mathrm{~g}$ for $5 \mathrm{~min}$, and incubated at $4^{\circ} \mathrm{C}$ for $18 \mathrm{~h}$. The tubes were then gently rotated until macroscopic clumps were no longer visible. The suspension was taken up in a Pasteur pipet and placed dropwise on vertical microscope slides.

B lymphocytes were identified by two techniques, detection of surface membrane immunoglobulin ( $\mathrm{smIg}$ ) with fluorescent rabbit anti-human immunoglobulin and the erythrocyte antibody complement (EAC)-rosette technique. The FicollHypaque-purified lymphocytes from patients with CLL were in all cases predominantly B cells, with a mean of $16 \% \mathrm{~T}$ cells and $<1 \%$ monocytes. Precise quantification of CLL lympho- cytes by fluorescent staining for smIg was hampered by the weakness of surface fluorescence, presumably a result of the reduced numbers of smIg molecules in these cells (13). Therefore, the EAC-rosette technique was also used, and it gave comparable results.

To prepare an antibody against smIg, immunoglobulin (Ig)G was purified from pooled, human sera by ammonium sulphate precipitation and separation on a DEAE-cellulose column (14). Antiserum was raised against this human IgG in New Zealand white rabbits, and the IgG in the rabbit antiserum was purified in a similar fashion. Immunoelectrophoresis demonstrated that the rabbit IgG reacted with the human IgG, as well as with IgA and IgM (because of activity against kappa and lambda chains). After conjugation with fluorescein isothiocyanate (Sigma Chemical Co., St. Louis, Mo.), the final concentration of the reagent was adjusted with buffered saline, which contained $1 \%$ bovine serum albumin (BSA, Sigma Chemical Co.), to be four times the minimum concentration necessary to label the maximum percentage of normal lymphocytes (15). The lymphocytes were assayed for smIg as follows: $5 \times 10^{5}$ labeled lymphocytes were placed in polypropylene 1.5- $\mathrm{ml}$ microtest tubes (Brinkman Instruments, Inc., Westbury, N. Y.), washed four times with buffered saline, and suspended in $50 \mu$ l of the conjugated antibody for $30 \mathrm{~min}$ at $0^{\circ} \mathrm{C}$. After this incubation, the cells were washed four more times and collected on microscope slides with the cytocentrifuge. After drying, the slides were fixed in methanol and counterstained with acridine orange $(0.7 \mu \mathrm{g} / \mathrm{ml}$ in $0.1 \mathrm{M}$ Tris- $\mathrm{HCl}, \mathrm{pH} 8.0)$. Fluorescence microscopy was carried out with an American Optical fluorescence microscope (American Optical Corp., Scientific Instruments Div., Buffalo, N. Y.) equipped with epi-illumination. At least 500 cells were examined.

For the EAC-rosette assay, SRBC were suspended at $5 \times 10^{8}$ cells $/ \mathrm{ml}$, incubated at $37^{\circ} \mathrm{C}$ for $30 \mathrm{~min}$ with a nonagglutinating titer of rabbit anti-SRBC IgM, washed twice, incubated at $37^{\circ} \mathrm{C}$ for $30 \mathrm{~min}$ with a nonhemolytic titer of human serum as a source of complement (stored at $-70^{\circ} \mathrm{C}$ ), washed twice, and adjusted to $10^{8}$ cell $/ \mathrm{ml}$ in veronal buffer (16). $100 \mu \mathrm{l}$ of this SRBC suspension was mixed with $10^{5}$ washed lymphocytes in $100 \mu \mathrm{l}$ veronal buffer, centrifuged at $400 \mathrm{~g}$ for $5 \mathrm{~min}$, and incubated in a $37^{\circ} \mathrm{C}$ water bath for $30 \mathrm{~min}$. After this, the supernate was removed and replaced with two drops of veronal buffer with $5 \%$ BSA at $37^{\circ} \mathrm{C}$. The cells were resuspended, and slides were made in the same manner as above. The specimens were concurrently stained for nonspecific esterase (17) to enable the elimination of monocyte EAC rosettes from the scoring.

Adenylate cyclase. The adenylate cyclase assay was modified from the method of Krishna et al. (18). 3-5 × $10^{6}$ lymphocytes were placed in polypropylene $1.5-\mathrm{ml}$ microtesttubes and were pelleted by centrifugation at $400 \mathrm{~g}$ for $1 \mathrm{~min}$, washed once in $4^{\circ} \mathrm{C}$ saline, and resuspended in $50 \mu \mathrm{l}$ of a hypotonic buffer which contained $2 \mathrm{mM}$ Tris- $\mathrm{HCl}, \mathrm{pH} \mathrm{7.5}$, $1 \mathrm{mM} \mathrm{MgSO}_{4}, 0.2 \%$ sucrose, and $1 \mathrm{mM}$ dithiothreitol, at $4^{\circ} \mathrm{C}$. After a 10 -min incubation at $4^{\circ} \mathrm{C}$, the cell suspension was rapidly frozen in liquid nitrogen and immediately thawed. An additional $50 \mu \mathrm{l}$ of incubation medium was added to give a final concentration of $25 \mathrm{mM}$ Tris- $\mathrm{HCl}, \mathrm{pH} 7.8,1 \mathrm{mM}$ cyclic AMP, $1.6 \mathrm{mM}$ ATP, $4 \mathrm{mM} \mathrm{MgCl}_{2}, 0.16 \% \mathrm{BSA}, 0.5 \mathrm{mg} / \mathrm{ml}$ creatine phosphokinase, $3 \mathrm{mg} / \mathrm{ml}$ creatine phosphate, and $1-2 \times 10^{6} \mathrm{cpm}\left[\alpha^{-{ }^{32}} \mathrm{P}\right] \mathrm{ATP}$. Additional concentrated solutions of chemicals and hormones were added in 2- to 4- $\mu$ l amounts to yield the stated final concentrations: $\mathrm{NaF}$ in saline, $10 \mathrm{mM}$; L-isoproterenol in $1 \mathrm{mM}$ ascorbic acid, $10 \mu \mathrm{M}$; D, L-propranolol in $1 \mathrm{mM}$ ascorbic acid, $10 \mu \mathrm{M}$; $5^{\prime}$-guanylyl imidodiphosphate $(\mathrm{Gpp}[\mathrm{NH}] \mathrm{p})$ in saline, $0.1 \mathrm{mM}$; and prostaglandin $\mathrm{E}_{1}$ in ethanol, $10 \mu \mathrm{M}$. Ethanol and ascorbate controls gave no 
difference in enzyme activity. After incubation for $20 \mathrm{~min}$ at $30^{\circ} \mathrm{C}$, the reaction was stopped by addition of $100 \mu \mathrm{l}$ of $40 \mathrm{mM}$ EDTA in $30 \mathrm{mM}$ Tris-HCl, $\mathrm{pH}$ 7.5. The material was then applied to a 2.5-g neutral alumina column in a Pasteur pipet and eluted with $3 \mathrm{ml} 40 \mathrm{mM}$ Tris- $\mathrm{HCl}, \mathrm{pH} 7.5(19,20)$. The eluate was mixed with $8.5 \mathrm{ml}$ of Bray's scintillation fluid and counted in a Beckman liquid scintillation spectrometer (Beckman Instruments, Inc., Spinco Div., Palo Alto, Calif.). Duplicate assays agreed to within $5.5 \pm 1.6 \%$.

The $\left[\alpha^{-32} \mathrm{P}\right] \mathrm{ATP}(10-30 \mathrm{Ci} / \mathrm{mM}$, New England Nuclear, Boston, Mass.) was purchased monthly and checked for purity by ascending thin-layer chromatography on Brinkman polygram CEL 300 PEI paper (Brinkman Instuments, Inc.) in a solution of $0.8 \mathrm{M} \mathrm{LiCl}$. More than $96 \%$ of the counts were in ATP. This labeled ATP was also tested in a blank reaction mixture to which the EDTA solution was added before the lymphocyte lysate. If $>400 \mathrm{cpm}$ were recovered as cyclic AMP in this blank, the $\left[\alpha^{-32} \mathrm{P}\right] \mathrm{ATP}$ was discarded (two occasions), and a fresh batch was obtained. The counts per minute levels observed in assays of base-line enzyme activity were $>900$.

A variety of methods were tested for optimal lysis of lymphocytes, including treatment with the detergent Triton X-100 (Rohm and Haas Co., Philadelphia, Pa.) (0.1\%), sonication at a number of energy levels with a Bronson sonifier (E. B. Bronson \& Co., Inc., Blue Island, Ill.), homogenization in a Potter-Elvehjem tissue grinder for varying numbers of strokes and time intervals, the cavitation in a Parr cell-disruption bomb (Parr Instrument Co., Moline, Ill.). In addition, one to three cycles of freeze-thawing in liquid nitrogen were evaluated. The method of hypotonic swelling followed by a single freeze-thaw step was found to yield optimal and consistent enzyme activity levels.

The composition of the reaction mixture was also standardized. The concentrations of both creatine phosphate and creatine phosphokinase were optimized. We established that addition of unlabeled cyclic AMP as a carrier prevented catabolism of labeled cyclic AMP. Addition of $4 \mathrm{mM}$ theophylline to the assay did not alter the levels of adenylate cyclase observed.

The product of the enzyme reaction in the assay was identified by thin-layer chromatography (see above) as $\left[{ }^{32} \mathrm{P}\right]$ cyclic AMP. Contaminating $\left[{ }^{32} \mathrm{P}\right]$ and labeled ATP, ADP, and AMP were quantitatively removed by the alumina column. Controls that contained $\left[{ }^{3} \mathrm{H}\right]$ cyclic AMP were run in parallel, and the recovery of label in cyclic AMP was $>97 \%$ at the end of the assay.

The protein content of the lymphocyte lysate was determined by the method of Lowry et al. (21).

Cyclic AMP. The assay for cyclic AMP was carried out on $5 \%$ TCA extracts of a washed, cell pellet of $3 \times 10^{6}$ lymphocytes, prepared as previously published (22). After freezing and thawing, the acid lysate was centrifuged at $2,000 \mathrm{~g}$ for $15 \mathrm{~min}$, and the supernate was extracted 5-10 times with ether to remove $\mathrm{TCA}$ and heated at $85^{\circ} \mathrm{C}$ for $60 \mathrm{~min}$ to remove the ether. An additional step was included to remove ATP: the extract was applied to a $1-\mathrm{g}$ alumina column (as above), eluted with $3.5 \mathrm{ml} 40 \mathrm{mM}$ Tris- $\mathrm{HCl}$ (pH 7.5), lyophilized, and resuspended in $\mathrm{H}_{2} \mathrm{O}$. The recovery was $>95 \%$.

Cyclic AMP levels were measured in duplicate by a competitive binding assay (23) with a cyclic AMP binding protein purified from lymphocyte cytoplasm. As previously described (22), the following components were added to the reaction mixture in the listed order to give a final volume of 200 $\mu \mathrm{l}: 20 \mu \mathrm{l}$ cell extract or cyclic AMP standard of known concentration; $1.65 \mathrm{pmol}(10 \mu \mathrm{l})$ of $\left[{ }^{3} \mathrm{H}\right]$ cyclic AMP $(24.1 \mathrm{Ci} / \mathrm{mM})$; $120 \mu \mathrm{l} 0.1 \mathrm{M} \mathrm{NaHPO}, \mathrm{pH} 7.0$, containing $16 \mathrm{mM}$ theophylline, an inhibitor of cyclic AMP phosphodiesterase; and $50 \mu \mathrm{l}$ of the binding protein extract containing $25 \mu \mathrm{g}$ protein. After incubation at room temperature for $4 \mathrm{~h}$, the reaction mixture was chilled and collected by filtration onto a nitrocellulose filter (24-mm diameter, 0.45- $\mu \mathrm{m}$ thick, Millipore Corp., Bedford, Mass.) and washed with $4^{\circ} \mathrm{C}$ buffer containing

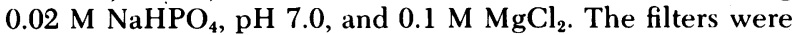
dissolved in Bray's solution and counted in a liquid scintillation spectrometer. A standard curve was run with each assay. Duplicates agreed to within $7.1 \pm 2.1 \%$.

Statistical methods. Results were compared by the twotailed Student's $t$ test.

Materials. L-Isoproterenol $d$-bitartarate was a gift of Sterling Drug Inc., Winthrop Laboratories, Rensselaer, N. Y. D,L-Propranolol-HCl was purchased from Sigma Chemical Co. Prostaglandin $\mathrm{E}_{1}\left(\mathrm{PGE}_{1}\right)$ was donated by Dr. John Pike of The Upjohn Co., Kalamazoo, Mich. $\left[\alpha^{32} \mathrm{P}\right] A T P$, as the tetra (triethylammonium) salt $(10-30 \mathrm{Ci} / \mathrm{mM})$ and $\left[{ }^{3} \mathrm{H}\right]$ cyclic AMP, as the ammonium salt $(30-50 \mathrm{Ci} / \mathrm{mM})$ were purchased from New England Nuclear. Cyclic AMP and ATP were from P-L Biochemicals, Inc., Milwaukee, Wis. Gpp(NH)p was purchased from ICN Pharmaceuticals, Inc., Life Sciences Group, Calif. Creatin kinase 1227245 and creatin phosphate 1426199 were obtained from Boehringer Mannheim Corp., Mannheim, West Germany.

\section{RESULTS}

Basal and stimulated adenylate cyclase and cyclic AMP levels. Adenylate cyclase and cyclic AMP were assayed in lymphocytes from normal donors and CLL patients (Fig. 1). When normal donors were considered in two groups $(<45 \mathrm{yr}$ and $>50 \mathrm{yr})$, no significant differences were observed. Likewise, differentiation by sex was insignificant. Therefore, data on basal levels, as well as responses to stimulation with hormones and $\mathrm{NaF}$, were pooled for all assays on lymphocytes from normal donors.

Assays of adenylate cyclase and cyclic AMP in CLL lymphocytes confirmed previous reports that generally

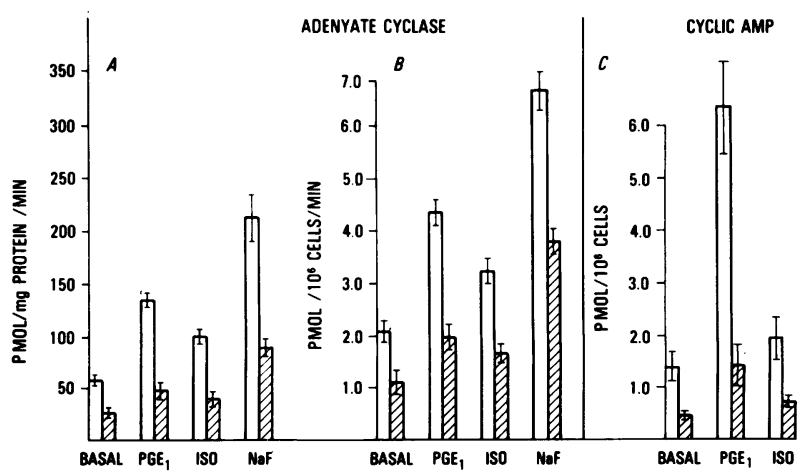

FIGURE 1 Adenylate cyclase activities and cyclic AMP levels in lymphocytes from normal donors and patients with CLL (mean \pm SEM). Open bars, normals; cross hatched bars, CLL. The adenylate cyclase activities are expressed as both picomoles $\left[{ }^{32} \mathrm{P}\right]$ cyclic AMP generated per milligram protein per minute and picomoles $\left[{ }^{32} \mathrm{P}\right]$ cyclic AMP generated per $10^{6}$ cells per minute. In all cases the values for CLL lymphocytes were significantly lower than for normal lymphocytes $(P<0.001)$. ISO, isoproterenol. 


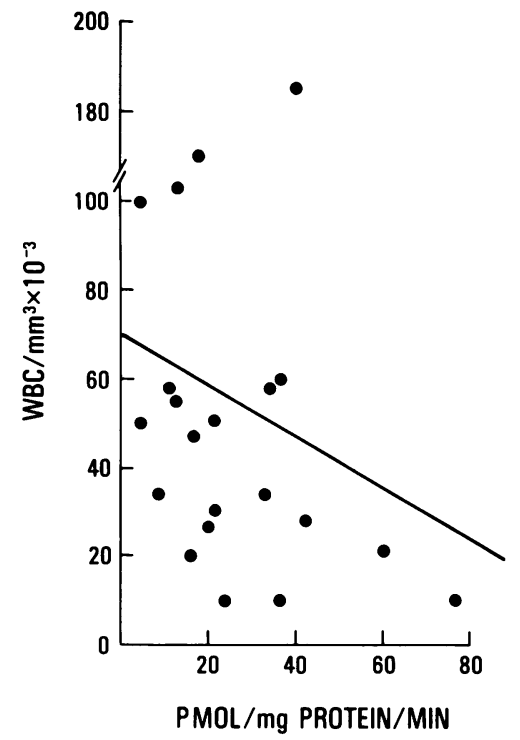

Figure 2 Test for correlation between peripheral leukocyte count and adenylate cyclase levels. The data were fitted to a linear curve by the least squares method. A significant correlation was not observed $(P>0.3)$. WBC, leukocytes.

found reduced levels in these cells (Fig. 1). The responses to hormonal stimulation and $\mathrm{NaF}$ were likewise lower than normal. These reductions were significant at the level of $P<0.001$, when the data were calculated either as the rate of cyclic AMP synthesis per milligram protein or as the rate of synthesis per $10^{6}$ cells (Fig. 1).

The extent of reduction in adenylate cyclase activity did not correlate significantly with the level of lymphocytosis (Fig. 2). Treatment status of the patient was also not a significant variable.

Characterization of abnormal response to hormones. The abnormal response of CLL lymphocyte adenylate cyclase to hormones or $\mathrm{NaF}$ might merely reflect the reduced basal enzyme activity, or it might be attributable to a specific reduced susceptibility of these cells to the normal stimulators of adenylate cyclase. Abnormalities in adenylate cyclase activities were analyzed in two ways: first differences between stimulated and basal levels were compared in the normal and patient populations; second, the ratios between stimulated and basal levels were examined (Table I). Whereas the first method of comparison resulted in significant $(P<0.001)$ differences between normals and patients, the ratios method of analyzing the response to stimulation did not distinguish normal from CLL lymphocytes. Thus, the relative adenylate cyclase activity is appropriately increased after exposure to hormones or $\mathrm{NaF}$, whereas the absolute values attained remain abnormal.

Analysis of T-and B-lymphocyte subpopulations. Because the CLL patients assessed in these studies had lymphoproliferative disorders involving the B-cell line, it was important to compare their peripheral lymphocyte cyclic AMP metabolism with normal B cells, which comprise less than one-third of the circulating lymphocytes analyzed to normal subjects. Therefore, adenylate cyclase was assayed in lymphocyte preparations enriched for $\mathrm{T}$ or $\mathrm{B}$ cells with standard purification procedures (Table II). To enrich for B cells, FicollHypaque-purified nomal lymphocytes were fractionated on a second Ficoll-Hypaque gradient after E rosetting with SRBC. To enrich for $T$ cells, the nylon wool adherence technique was used in preference to the E-rosetting method (Methods) because we wished to avoid treatment with ammonium chloride or hypotonic shock (to lyse erythrocytes) immediately before assaying for adenylate cyclase activity. The purification procedures yielded preparations of normal cells containing 90\% $\mathrm{T}$ and $8 \% \mathrm{~B}$ lymphocytes ( $\mathrm{T}$ enriched), and $34 \%$ $\mathrm{T}$ and $60 \% \mathrm{~B}$ lymphocytes (B enriched). The Ficoll-

TABLE I

Comparisons of Adenylate Cyclase Activities

\begin{tabular}{|c|c|c|c|c|c|c|c|c|c|c|c|c|}
\hline $\begin{array}{l}\text { Lymphocyte } \\
\text { donor }\end{array}$ & \multicolumn{2}{|c|}{$\mathrm{PGE}_{1}-\mathrm{basal}^{*}$} & \multicolumn{2}{|l|}{$\mathrm{PGE}_{1}$ :basal } & \multicolumn{2}{|c|}{ ISO - basal* } & \multicolumn{2}{|l|}{ IS():batsal } & \multicolumn{2}{|c|}{ NaF-basal* } & \multicolumn{2}{|c|}{ NaF:basal } \\
\hline & $\begin{array}{r}\text { pm } \\
\text { prot }\end{array}$ & $\begin{array}{l}l / m g \\
i n / m i n\end{array}$ & & & $\begin{array}{r}\text { pmo } \\
\text { prote }\end{array}$ & $\begin{array}{l}l / m g \\
i n / m i n\end{array}$ & & & $\begin{array}{c}\text { pmoll } \\
\text { protein }\end{array}$ & Img & & \\
\hline $\begin{array}{l}\text { Normal (21) } \\
\text { CLL }(20)\end{array}$ & $\begin{array}{l}75 \pm 7 \\
22 \pm 3\end{array}$ & $<0.001$ & & & $\left.\begin{array}{l}43 \pm 5 \\
15 \pm 2\end{array}\right]$ & $<0.001$ & & & $\left.\begin{array}{c}155 \pm 10 \\
63 \pm 5\end{array}\right]$ & $<0.001$ & & \\
\hline $\begin{array}{l}\text { Normal (21) } \\
\text { CLL (20) }\end{array}$ & & & $\left.\begin{array}{l}2.3 \pm 0.1 \\
2.2 \pm 0.3\end{array}\right]$ & NS & & & $\left.\begin{array}{l}1.8 \pm 0.1 \\
1.9 \pm 0.1\end{array}\right]$ & NS & & & $\left.\begin{array}{l}3.9 \pm 0.2 \\
4.8 \pm 0.7\end{array}\right]$ & NS \\
\hline
\end{tabular}

Upper panel shows the difference between stimulated and basal values; lower panel shows ratios. Results of statistical analysis are in brackets, using Student's $t$ test ( $P$ values). The numbers in parentheses refer to the number of experiments performed.

* Values shows are mean \pm SEM. 
TABLE II

Adenylate Cyclase Activities in Partially Purified Lymphocytes

\begin{tabular}{|c|c|c|c|c|c|c|}
\hline \multirow[t]{2}{*}{ Lymphocytes } & \multicolumn{2}{|c|}{ Differential } & Basal & $\mathrm{PGE}_{1}$ & ISO & $\mathrm{NaF}$ \\
\hline & $\% T$ & $\% B$ & \multicolumn{4}{|c|}{ pmol/mg protein $/ \mathrm{min}$} \\
\hline $\begin{array}{l}\text { Normal T-enriched (7) } \\
\text { Normal B-enriched (4) } \\
\text { CLL B-enriched (21) } \\
\text { CLL T-enriched (4) }\end{array}$ & $\begin{array}{l}90 \pm 3 \\
34 \pm 2 \\
16 \pm 4 \\
59 \pm 6\end{array}$ & $\begin{array}{r}8 \pm 4 \\
60 \pm 2 \\
84 \pm 6 \\
41 \pm 1\end{array}$ & 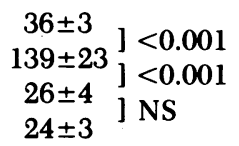 & 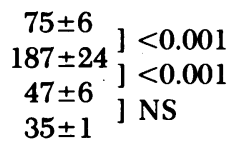 & 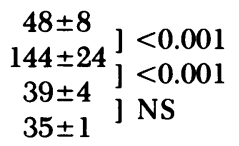 & 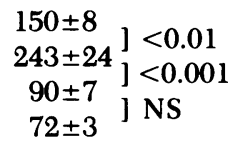 \\
\hline
\end{tabular}

Data as in Table I.

Hypaque-purified lymphocytes from CLL patients contained $16 \% \mathrm{~T}$ and $84 \% \mathrm{~B}$ cells, and the T-enriched CLL preparations contained $59 \% \mathrm{~T}$ and $41 \%$ B lymphocytes. Enzyme assays on the fractionated normal lymphocyte subpopulations demonstrated significant differences between T-enriched and B-enriched preparations (Table II). Likewise, normal, B-enriched lymphocytes differed significantly from CLL lymphocytes.

The possibility was considered that artifactual differences between $\mathrm{T}$ and $\mathrm{B}$ cells could be generated as a result of the two purification techniques used. It should be noted that both nylon wool purification and E-rosetting fractionation resulted in data demonstrating that $\mathrm{T}$ enrichment lowered and $\mathrm{T}$ depletion (B enrichment) elevated adenylate cyclase activity (Table II).

In three control experiments, enzyme activity was measured in B-enriched and T-enriched preparations obtained with a single fractionation method, the E-rosetting procedure. In this case, $T$ cells were obtained by incubating Ficoll-Hypaque-purified E-rosetted lymphocytes at $37^{\circ} \mathrm{C}$ and vortexing for $30 \mathrm{~s}$, followed by recentrifugation on a third Ficoll-Hypaque gradient. This recovery method avoids the perturbation of a lytic step, but produces an extremely poor yield of $\mathrm{T}$ cells. The results of three such experiments demonstrated elevation of adenylate cyclase with B enrichment and reduction of enzyme activity with $\mathrm{T}$ enrichment (Table III). The following additional control experiments were performed. (a) Adenylate cyclase activity in Ficoll-Hypaque-purified lymphocytes (the standard controls) was not significantly altered when parallel cell preparations were further processed as if for B-cell purification on an additional Ficoll-Hypaque gradient, but in the absence of SRBC (four experiments). (b) Adenylate cyclase activities were comparable when a nylon wool column T-cell-enriched population was compared with $\mathrm{T}$ cells purified by $\mathrm{E}$ rosetting, and with both purification methods the enzyme activities were reduced compared with the control Ficoll-Hypaque preparations that contained fewer $\mathrm{T}$ cells (three experiments). (c) When Ficoll-Hypaque-purified lymphocytes were incubated on nylon wool columns for $45 \mathrm{~min}$ and then eluted rapidly at room temperature so that the $T: B$ ratio was nearly identical to the precolumn ratio, adenylate cyclase activity was not altered (three experiments).

The above considerations strongly suggest that the T- and B-cell differences observed did not result from the purification methods used.

The data presented in Table II provide the possibility of setting up simultaneous equations to solve for the adenylate cyclase levels in pure B-and pure T-lymphocyte subpopulations. With this procedure, the calculated adenylate cyclase activities of normal $\mathrm{T}$ cells under basal conditions and after hormonal stimulation were $<20 \%$ of the enzyme activities calculated for normal B cells (Table IV). In contrast, CLL B cells had calculated adenylate cyclase levels similar to normal $\mathrm{T}$ cells, and far below those observed in normal B cells. The calculated values of pure T- and B-lymphocyte

TABLE III

Adenylate Cyclase Activities in Ficoll-Hypaque-Purified Lymphocyte Subpopulations

\begin{tabular}{|c|c|c|c|c|c|c|c|c|c|c|c|c|}
\hline \multirow[b]{3}{*}{$\begin{array}{l}\text { Ficoll-Hypaque purified (3) } \\
\text { B enriched (3) } \\
\text { T enriched (3) }\end{array}$} & \multicolumn{3}{|c|}{ Basal } & \multicolumn{3}{|c|}{$\mathrm{PGE}_{1}$} & \multicolumn{3}{|c|}{ Basal } & \multicolumn{3}{|c|}{$\mathrm{PGE}_{1}$} \\
\hline & \multicolumn{6}{|c|}{ pmol/10 cells/min } & \multicolumn{6}{|c|}{$\mathrm{pmol} / \mathrm{mg}$ protein $/ \mathrm{min}$} \\
\hline & $<0.001$ & {$\left[\begin{array}{l}1.84 \pm 0.08 \\
2.76 \pm 0.06 \\
1.10 \pm 0.13\end{array}\right]$} & $<0.01$ & $<0.01$ & {$\left[\begin{array}{l}4.41 \pm 0.20 \\
7.86 \pm 0.42 \\
3.06 \pm 0.07\end{array}\right]$} & $<0.01$ & $<0.02$ & $\begin{array}{l}53 \pm 2 \\
63 \pm 2 \\
34 \pm 4\end{array}$ & $<0.05$ & $<0.01$ & $\begin{array}{c}127 \pm 6 \\
178 \pm 10 \\
94 \pm 2\end{array}$ & $<0.01$ \\
\hline
\end{tabular}

The Ficoll-Hypaque-purified preparations contained $70 \pm 3 \% \mathrm{~T}$ cells and $22 \pm 3 \%$ B lymphocytes. The B-enriched subpopulation, derived from the interface of a second Ficoll-Hypaque gradient after $\mathrm{E}$ rosetting, contained $25 \pm 5 \% \mathrm{~T}$ cells and $63 \pm 7 \%$ B lymphocytes. The $\mathrm{T}$-enriched subpopulation, derived from the E-rosetted pellet of the second Ficoll-Hypaque gradient, contained $88 \pm 2 \% \mathrm{~T}$ lymphocytes and $4 \pm 2 \% \mathrm{~B}$ cells. The numbers in parentheses refer to the number of experiments performed. 
TABLE IV

Calculated Adenylate Cyclase Activities for Pure T-and B-Lymphocyte Subpopulations

\begin{tabular}{|c|c|c|c|c|c|c|c|}
\hline $\begin{array}{l}\text { Lymphocyte } \\
\text { donor }\end{array}$ & Basal & $\mathrm{PGE}_{1}$ & $\mathrm{PGE}_{2}$ : basal & ISO & ISO:basal & $\mathrm{NaF}$ & NaF:basal \\
\hline & $\begin{array}{c}\text { pmol/mg } \\
\text { protein/min }\end{array}$ & $\begin{array}{c}\text { pmol/mg } \\
\text { protein/min }\end{array}$ & & $\begin{array}{c}\text { pmol/mg } \\
\text { protein/min }\end{array}$ & & $\begin{array}{c}\text { pmol/mg } \\
\text { protein/min }\end{array}$ & \\
\hline CLL B & $34 \pm 6$ & $52 \pm 9$ & & $46 \pm 7$ & & $96 \pm 11$ & \\
\hline Normal B & $196 \pm 22$ & $314 \pm 45$ & & $267 \pm 36$ & & $434 \pm 50$ & \\
\hline Normal T & $30 \pm 10$ & $50 \pm 13$ & & $45 \pm 13$ & & $118 \pm 16$ & \\
\hline CLL T & $19 \pm 4$ & $23 \pm 7$ & & $26 \pm 7$ & & $69 \pm 12$ & \\
\hline CLL B & & & $1.6 \pm 0.2$ & & $1.4 \pm 0.2$ & & $3.0 \pm 0.5$ \\
\hline Normal B & & & $1.7 \pm 0.5$ & & $1.7 \pm 0.4$ & & $2.9 \pm 0.7$ \\
\hline Normal T & & & $1.4 \pm 0.4$ & & $1.8 \pm 0.5$ & & $5.1 \pm 1.0$ \\
\hline CLL T & & & $1.2 \pm 0.3$ & & $1.3 \pm 0.4$ & & $3.7 \pm 0.2$ \\
\hline
\end{tabular}

Data as in Table I.

adenylate cyclase activities were then reassessed to determine whether differences in the pattern of response to hormonal and $\mathrm{NaF}$ stimulation could now be detected. The ratios of stimulated to basal adenylate cyclase levels did not differ between normal lymphocytes, CLL B cells and CLL T lymphocytes (Table IV). This further supports the conclusion that whereas the base-line activities vary in these lymphocyte subpopulations, the relative response to stimulation is not abnormal in CLL lymphocytes.

Comparison of adenylate cyclase assays with normal and leukemic lymphocytes. Experiments were designed to rule out trivial explanations for observed differences between adenylate cyclase activities. Linearity of the assay over a 30 -min incubation period and a linear relation between cell number and enzyme activity were established for the two lymphocyte populations under study (Fig. 3A and 3B). The optimal $\mathrm{Mg}^{++}$concentration was $4 \mathrm{mM}$ in both cases (Fig. $3 \mathrm{C}$ ).
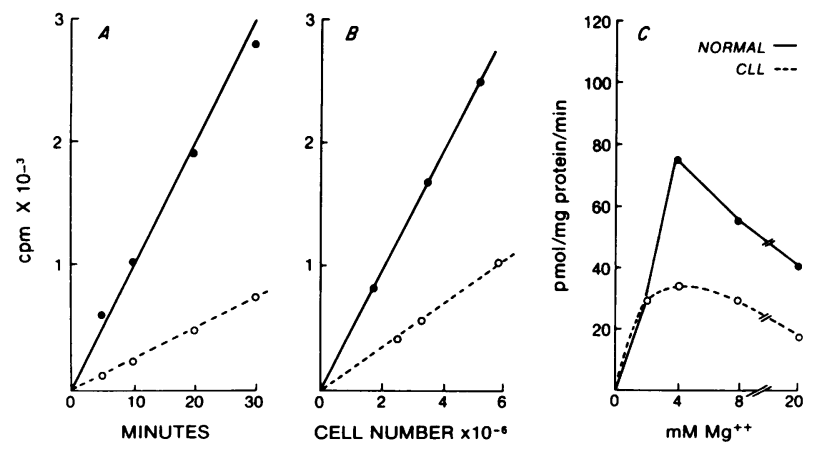

Figure 3 Assay for adenylate cyclase. (A) Production of ${ }^{32} \mathrm{P}$ counts in cyclic AMP as a function of incubation time. (B) Production of ${ }^{32} \mathrm{P}$ counts in cyclic AMP during a 20-min incubation period, as a function of cell number. (C) Production of $\left[{ }^{32} \mathrm{P}\right]$ cyclic AMP during a 20 -min incubation period as a function of $\mathrm{Mg}^{++}$concentration.
The optimal concentrations of ISO and $\mathrm{PGE}_{1}$ in the adenylate cyclase assay were found to be $10-100 \mu \mathrm{M}$ in both cases.

To further compare the response of normal and CLL lymphocytes with hormones and chemical stimuli, two series of experiments were carried out assessing the effects of exposure to the $\beta$-adrenergic antagonist, propranolol, and to $\mathrm{Gpp}(\mathrm{NH}) \mathrm{p}$ (24) (Table V). As before, the method of ratios was used to compare adenylate cyclase activities in the presence and absence of these agents. In both normal and CLL lymphocytes, the elevation in adenylate cyclase activity resulting from incubation with ISO was completely prevented by simultaneous addition of propranolol, whereas the

TABLE V

Adenylate Cyclase Activities

\begin{tabular}{|c|c|c|c|c|}
\hline Agents & \multicolumn{2}{|c|}{ Normal } & \multicolumn{2}{|r|}{ CLL } \\
\hline \multicolumn{5}{|l|}{ Experiment I } \\
\hline Basal & 55 & & 24 & \\
\hline Pro & 39 & & 16 & \\
\hline ISO & 86 & \multirow{2}{*}{$r=2.2$} & 41 & \multirow{2}{*}{$r=2.7$} \\
\hline ISO + Pro & 39 & & 15 & \\
\hline $\mathrm{PGE}_{1}$ & 115 & \multirow{2}{*}{$r=1.0$} & 44 & \multirow{2}{*}{$r=1.0$} \\
\hline $\mathrm{PGE}_{1}+$ Pro & 102 & & 44 & \\
\hline \multicolumn{5}{|l|}{ Experiment II } \\
\hline Basal & 71 & & 30 & \\
\hline $\mathrm{Gpp}(\mathrm{NH}) \mathrm{p}$ & 117 & & 70 & \\
\hline $\mathrm{PGE}_{1}$ & 140 & \multirow{2}{*}{$r=1.9$} & 46 & \multirow{2}{*}{$r=1.9$} \\
\hline $\mathrm{PGE}_{1}+\mathrm{Gpp}(\mathrm{NH}) \mathrm{p}$ & 264 & & 86 & \\
\hline ISO & 96 & \multirow{2}{*}{$r=2.0$} & 44 & \multirow[t]{2}{*}{$r=1.9$} \\
\hline $\mathrm{ISO}+\mathrm{Gpp}(\mathrm{NH}) \mathrm{p}$ & 194 & & 84 & \\
\hline $\mathrm{NaF}$ & 230 & \multirow{2}{*}{$r=1.0$} & 89 & \multirow{2}{*}{$r=1.0$} \\
\hline $\mathrm{NaF}+\mathrm{Gpp}(\mathrm{NH}) \mathrm{p}$ & 241 & & 91 & \\
\hline
\end{tabular}

Data as in Table I. $(r)$ refers to ratio of two values. Pro is propranolol. 
latter agent had no effect upon the elevation in enzyme activity induced by $\mathrm{PGE}_{1}$. Addition of $\mathrm{Gpp}(\mathrm{NH}) \mathrm{p}$ concurrently with ISO or $\mathrm{PGE}_{1}$ resulted in a further rise in adenylate cyclase activity, which was identical in normal and CLL lymphocytes. Thus, a pattern of normal reactivity to hormones and other modulating agents continued to be observed in CLL lymphocytes, although the absolute enzyme activities were, in all cases, reduced in CLL.

\section{DISCUSSION}

Depression of adenylate cyclase activity in CLL lymphocytes has been reported previously $(3,4)$. Polgar et al. (3) found that the response of CLL lymphocyte adenylate cyclase to stimulation with $\mathrm{NaF}$ was intact, although levels somewhat below those of normal lymphocytes were attained. The responses to ISO and $\mathrm{PGE}_{1}$ were essentially nil. Sheppard et al. (4) also reported reduced adenylate cyclase activity in CLL, with a far more active response to $\mathrm{NaF}$ than to ISO. In our studies, we observed depressed enzyme activity of basal adenylate cyclase and low levels after stimulation with ISO, $\mathrm{PGE}_{1}$, or $\mathrm{NaF}$. In contrast, the ratios of stimulated to basal levels in leukemic and normal lymphocytes did not differ. Furthermore, CLL cells and normal lymphocytes had similar responses to propranolol, a $\beta$-adrenergic blocking agent, and to $\mathrm{Gpp}(\mathrm{NH}) \mathrm{p}$, a nucleotide analogue of guanosine triphosphate, which stimulates adenylate cyclase and potentiates its response to hormones. These observations are consistent with the conclusion that whereas adenylate cyclase activity is reduced in CLL, the enzyme can function normally in its interaction with environmental influences. The simplest conclusion is that the number of enzyme sites on the surface membranes of CLL lymphocytes is reduced, although alternative explanations are possible. Sheppard et al. (4) have provided evidence that reduced adenylate cyclase in CLL lymphocytes may be associated with a reduced number of binding sites for naturally occurring hormonal regulators. ISO binding, assessed by assaying the binding of $\left[{ }^{3} \mathrm{H}\right]$ dihydroalprenolol to CLL lymphocytes was found to be diminished 6.5-fold. This factor is similar to the 6.4-fold reduction in basal enzyme activity observed in our study. It is of interest that the number of receptor sites for phytohemagglutinin is also diminished on the surface membranes of CLL lymphocytes (25). Likewise, the number of smIg receptor sites is reduced (13).

In the previous study of Polgar et al. (3), the purification method for obtaining normal control lymphocytes was sedimentation, which results in enrichment of the study population for $T$ cells (unpublished observations). Likewise, Sheppard et al. (4) enriched for $\mathrm{T}$ cells with their method of preparing normal lymphocytes for study because they used adherence to plastic and to nylon wool as purification methods. Our data, which rely on a comparison of normal B cells with B lymphocytes from CLL patients, shows a far more striking difference (more than sixfold) between the two populations. Our observed basal level of adenylate cyclase activity in CLL lymphocytes is comparable to the findings of Sheppard et al. (14), who likewise expressed enzyme activity in picomoles of ATP synthesized per milligram protein per minute.

It must be remembered that the subpopulations of lymphocytes that we studied had undergone extensive fractionation procedures and were in a cellular environment quite different from their normal in vivo situations. These perturbations may have contributed to the observed data in the in vitro assays of basal and stimulated adenylate cyclase activities.

Basal cyclic AMP levels in CLL lymphocytes have been assayed by two groups $(5,6)$. In one case, cyclic AMP levels were reduced compared with normal lymphocytes, whereas in the other they were elevated. In agreement with Monahan et al. (5), we find reduced basal cyclic AMP concentrations in CLL lymphocytes. The levels attained in response to stimulation with $\mathrm{PGE}_{1}$ or ISO are also below normal. This may be attributable to the reduced adenylate cyclase activity. It is probably not a result of alterations in phosphodiesterase activity, because the most comprehensive study of phosphodiesterase in CLL lymphocytes showed a decrease in the activity of this enzyme (7). However, it should be noted that cyclic AMP phosphodiesterase activity is elevated in murine leukemia (26) and leukemic cell lines (27).

The significance of the reduction in adenylate cyclase and cyclic AMP in CLL lymphocytes is conjectural. It is generally accepted that in human lymphocytes the proliferative responses to stimulation by antigens and mitogens is reduced as a result of exposure to added cyclic AMP $(1,2,28)$. In contrast, human lymphocytes stimulated to divide with phytohemagglutinin have reduced cyclic AMP levels (after a transient increase immediately after addition of the lectin) $(22,29)$. One might think of the CLL B cell as a stimulated clone which displays increased cell division and increased differentiation when compared with normal, circulating B lymphocytes. Although the fraction of CLL cells in the peripheral blood that are actively cycling may not be increased (30), malignant B cells in the enlarged lymph nodes of patients with CLL undergo increased division (31). In general, transformed malignant cells have reduced cyclic AMP levels when compared with cells with normal growth patterns; conversely, stimulation of increased cyclic AMP levels results in diminished growth in a wide variety of cultured cells (32). 
Cyclic AMP levels have been assayed previously in studies of lymphocyte populations and subpopulations obtained from a number of murine and human lymphoid organs $(33,34)$. Purified, human $T$ cells had cyclic AMP levels of 1-2 pmol/106 cells, with higher values in peripheral blood cells than in thymocytes; purified B cells from tonsils and adenoids had levels of $6 \mathrm{pmol} / 10^{6}$ cells. Reduced cyclic AMP levels were also observed in human peripheral $\mathrm{T}$ cells by Atkinson et al. (35). Thus, our observation of higher adenylate cyclase activity in circulating human B cells is quite consistent with the present and previous reports on cyclic AMP levels in human lymphocyte subpopulations.

The observations that adenylate cyclase activities, along with cyclic AMP levels, are lower in T cells than $\mathrm{B}$ cells in man raise some interesting questions for future study. At present, we have no evidence that circulating $\mathrm{T}$ cells are more actively cycling or functioning more than circulating B cells, but this is a testable hypothesis. In addition, it remains to be determined whether the differences between $B$ and $T$ lymphocytes persist after stimulation by antigens or mitogens.

\section{ACKNOWLEDGMENTS}

Doctors Thomas Shiftan and Alendry P. Caviles, Jr. contributed to the development of the lymphocyte identification assays. Dr. Robert Parmer participated in early experiments, as a medical student research project. We thank Ms. Jerrilyn Sober for help in the preparation of this manuscript.

This study was supported by National Institutes of Health research grants CM22637 and CA11971.

\section{REFERENCES}

1. Wedner, H. J., and C. W. Parker. 1976. Lymphocyte activation. Prog. Allergy. 20: 195-300.

2. Parker, C. W. 1977. Cyclic nucleotides in the immune response. In Cyclic 3',5'-Nucleotides: Mechanisms of Action. H. Cramer and J. Schultz, editors. John Wiley \& Sons, Inc., New York. 161-187.

3. Polgar, P., J. C. Vera, P. R. Kelley, and A. M. Rutenburg. 1973. Adenylate cyclase activity in normal and leukemic human leukocytes as determined by a radioimmunoassay for cyclic AMP. Biochim. Biophys. Acta. 297: 378-383.

4. Sheppard, J. R., R. Gormus, and C. F. Moldow. 1977. Catecholamine hormone receptors are reduced on chronic lymphocytic leukaemic lymphocytes. Nature (Lond.). 269: 693-695.

5. Monahan, T. M., N. W. Marchand, R. R. Fritz, and C. W. Abell. 1975. Cyclic adenosine $3^{\prime}: 5^{\prime}$-monophosphate levels and activities of related enzymes in normal and leukemic lymphocytes. Cancer Res. 35: 2540-2547.

6. Polgar, P., J. C. Vera, and A. M. Rutenburg. 1977. An altered response to cyclic AMP stimulating hormones in intact human leukemic lymphocytes (39701). Proc. Soc. Exp. Biol. Med. 154: 493-495.

7. Scher, N. S., F. Quagliata, V. G. Malathi, D. Faig, R. A. Melton, and R. Silber. 1976. Cyclic adenosine $3^{\prime}: 5^{\prime}$ monophosphate phosphodiesterase activity in normal and chronic lymphocytic leukemia lymphocytes. Cancer Res. 36: $3958-3962$.
8. Mendelsohn, J., S. A., Skinner, and S. Kornfeld. 1971. The rapid induction by phytohemagglutinin of increased $\alpha$-aminoisobutyric acid uptake by lymphocytes. J. Clin. Invest. 50: 818-826.

9. Jondal, M. 1976. SRBC rosette formation as a human T lymphocyte marker. Scand.J.Immunol. 5(Suppl.): 69-76.

10. Wahl, S. M., D. L. Rosenstreich, and J. J. Oppenheim. 1976. Separation of human lymphocytes by $\mathrm{E}$ rosette sedimentation. In In Vitro Methods in Cell-Mediated and Tumor Immunity. B. R. Bloom and J. R. David, editors. Academic Press, Inc., New York. 231-240.

11. Julius, M. H., E. Simpson, and L. A. Herzenberg. 1973. A rapid method for the isolation of functional thymusderived murine lymphocytes. Eur.J. Immunol. 3: 645-649.

12. Hepburn, B., and R. E. Ritts. 1974. Human T lymphocytes. Assay method using permanently fixed slides. Mayo Clin. Proc. 49: 866-869.

13. Dickler, H. B., F. P. Siegal, Z. H. Bentwich, and H. G. Kunkel. 1973. Lymphocyte binding of aggregated IgG and surface Ig staining in chronic lymphocytic leukaemia. Clin. Exp. Immunol. 14: 97-106.

14. Fahey, J. L., and E. W. Terry. 1967. Ion exchange chromatography and gel filtration. In Handbook of Experimental Immunology. D. M. Weir, editor. Blackwell Scientific Publications Ltd., Oxford, England. 1: 7.1-7.16.

15. Johnson, D. G., and E. J. Holborow. 1973. Immunofluorescence. In Handbook of Experimental Immunology. D. M. Weir, editor. Blackwell Scientific Publications Ltd., Oxford, England. 1: 18.1-18.20.

16. Bianco, C., R. Patrick, and V. Nussenzweig. 1970. A population of lymphocytes bearing a membrane receptor for antigen-antibody-complement complexes.J. Exp. Med. 132: 702-720.

17. Yam, L. T., C. Y. Li, and W. H. Crosby. 1971. Cytochemical identification of monocytes and granulocytes. Am. J. Clin. Pathol. 55: 283-290.

18. Krishna, G., B. Weiss, and B. B. Brodie. 1968. A simple, sensitive method for the assay of adenyl cyclase. $J$. Pharmacol. Exp. Ther. 153: 397-385.

19. Ramachandran, J. 1971. A new simple method for separation of adenosine $3^{\prime}, 5^{\prime}$-cyclic monophosphate from other nucleotides and its use in the assay of adenyl cyclase. Anal. Biochem. 43: 227-239.

20. White, A. A., and T. V. Zenser. 1971. Separation of cyclic 3',5'-nucleoside monophosphates from other nucleotides on aluminum oxide columns. Application to the assay of adenyl cyclase and guanyl cyclase. Anal. Biochem. 41: 372-396.

21. Lowry, O. H., N. J. Rosebrough, A. L. Farr, and R. J. Randall. 1951. Protein measurement with the Folin phenol reagent. J. Biol. Chem. 193: 265-275.

22. Mendelsohn, J., M. M. Multer, and R. F. Boone. 1973. Enhanced effects of prostaglandin $E_{1}$ and dibutyryl cyclic AMP upon human lymphocytes in the presence of cortisol. J. Clin. Invest. 52: 2129-2137.

23. Walton, G. M., and L D. Garren. 1970. An assay for adenosine $3^{\prime}, 5^{\prime}$-cyclic monophosphate based on the association of the nucleotide with a partially purified binding protein. Biochemistry. 9: 4223-4229.

24. Londos, C., Y. Salomon, M. D. Lin, J. P. Harwood, M. Schramm, J. Wolff, and M. Rodbell. 1974. 5'-guanylylimidodiphosphate, a potent activator of adenylate cyclase systems in eukaryotic cells. Proc. Natl. Acad. Sci. U. S. A. 71: 3087-3090.

25. Kornfeld, S. 1969. Decreased phytohemagglutinin receptor sites in CLL. Biochim. Biophys. Acta. 192: 542-545.

26. Menahan, L. A., and R. G. Kemp. 1976. Cyclic 3',5'adenosine monophosphate phosphodiesterase in the 
thymus of normal and leukemic mice.J. Cyclic Nucleotide Res. 2: 417-425.

27. Hait, W. N., and B. Weiss. 1977. Characteristics of the cyclic nucleotide phosphodiesterases of normal and leukemic lymphocytes. Biochim. Biophys. Acta. 497: 86- 100.

28. Smith, J. W., A. L. Steiner, and C. W. Parker. 1971. Human lymphocyte metabolism. Effects of cyclic and noncyclic nucleotides on stimulation by phytohemagglutinin. J. Clin. Invest. 50: 442-448.

29. Smith, J. W., A. L. Steiner, W. M. Newberry, Jr., and C. W. Parker. 1971. Cyclic adenosine 3',5'-monophosphate in human lymphocytes. Alterations after phytohemagglutinin stimulation. J. Clin. Invest. 50: 432-441.

30. Stryckmans, P. A., L. Debusscher, and E. Collard. 1977. Cell kinetics in chronic lymphocytic leukaemia (CLL). Clin. Haematol. 6: 159-167.

31. Theml, H., F. Trepel, P. Schick, W. Kaboth, and H.
Begemann. 1973. Kinetics of lymphocytes in chronic lymphocytic leukemia: studies using continuous ${ }^{3} \mathrm{H}$-thymidine infusion in two patients. Blood. 42: 623-636.

32. Schönhöfer, P. S., and H. D. Peters. 1977. Role of cyclic nucleotides in cultured cells. In Cyclic 3',5'-Nucleotides: Mechanisms of Action. H. Cramer and J. Schultz, editors. John Wiley \& Sons, Inc., New York. 107-131.

33. Bach, M-A. 1975. Differences in cyclic AMP changes after stimulation by prostaglandins and isoproterenol in lymphocyte subpopulations. J. Clin. Invest. 55: 1074-1081.

34. Niaudet, P., G. Beaurain, and M-A. Bach. 1976. Differences in effect of isoproterenol stimulation on levels of cyclic AMP in human B and T lymphocytes. Eur. J. Immunol. 6: 834-836.

35. Atkinson, J. P., H. J. Wedner, and C. W. Parker. 1975. Two novel stimuli of cyclic adenosine $3^{\prime}, 5^{\prime}$-monophosphate (cAMP) in human lymphocytes. J. Immunol. 115: 1023-1027. 